\title{
COVID-19 and ischemic stroke: Mechanisms of hypercoagulability (Review)
}

\author{
SHUOQI ZHANG ${ }^{1,2}$, JINMING ZHANG $^{2}$, CHUNXU WANG $^{2}$, XIAOJING CHEN $^{2}$, XINYI ZHAO $^{3}$, \\ HAIJIAO JING ${ }^{2}$, HUAN LIU ${ }^{2}$, ZHUXIN LI ${ }^{4}$, LIHUA WANG ${ }^{1 *}$ and JIALAN SHI ${ }^{2,5,6 *}$ \\ ${ }^{1}$ Department of Neurology, The Second Hospital, Harbin Medical University; ${ }^{2}$ Department of Hematology, \\ The First Hospital, Harbin Medical University; ${ }^{3}$ Department of Cardiology, The Second Hospital, \\ Harbin Medical University, Harbin, Heilongjiang 150001; ${ }^{4}$ Department of Acupuncture and Moxibustion, \\ College of Acupuncture and Moxibustion, Heilongjiang University of Chinese Medicine, Harbin, \\ Heilongjiang 150040, P.R. China; ${ }^{5}$ Department of Medicine, Brigham and Women's Hospital, Harvard Medical School; \\ ${ }^{6}$ Department of Research, VA Boston Healthcare System, Harvard Medical School, Boston, MA 02132, USA
}

Received August 17, 2020; Accepted December 15, 2020

DOI: $10.3892 /$ ijmm.2021.4854

\begin{abstract}
During the coronavirus disease 2019 (COVID-19) pandemic, some patients with severe COVID-19 exhibited complications such as acute ischemic stroke (AIS), which was closely associated with a poor prognosis. These patients often had an abnormal coagulation, namely, elevated levels of D-dimer and fibrinogen, and a low platelet count. Certain studies have suggested that COVID-19 induces AIS by promoting hypercoagulability. Nevertheless, the exact mechanisms through which COVID-19 leads to a hypercoagulable state in infected patients remain unclear. Understanding the underlying mechanisms of hypercoagulability is of utmost importance for the effective treatment of these patients. The present review aims to summarize the current status of research on COVID-19, hypercoagulability and ischemic stroke. The present review also aimed to shed light into the underlying mechanisms through which COVID-19 induces hypercoagulability, and to provide therapies for different mechanisms for the more effective treatment of patients with COVID-19 with ischemic stroke and prevent AIS during the COVID-19 pandemic.
\end{abstract}

Correspondence to: Professor Lihua Wang, Department of Neurology, The Second Hospital, Harbin Medical University, 246 Xuefu Road, Nangang, Harbin, Heilongjiang 150001, P.R. China E-mail: wanglihuatongxun@163.com

Professor Jialan Shi, Department of Hematology, The First Hospital, Harbin Medical University, 23 Youzheng Street, Nangang, Harbin, Heilongjiang 150001, P.R. China

E-mail: jialan_shi@hms.harvard.edu

${ }^{*}$ Contributed equally

Key words: COVID-19, coronavirus, acute ischemic stroke, hypercoagulability, anticoagulation

\section{Contents}

1. Introduction

2. Hypercoagulability and thrombosis in patients with COVID-19

3. COVID-19 and acute ischemic stroke

4. Mechanisms of hypercoagulability in COVID-19

5. Antithrombotic therapy for COVID-19

6. Prevention of acute ischemic stroke

7. Conclusions and future perspectives

\section{Introduction}

Coronavirus disease 2019 (COVID-19) is an illness resulting from the novel severe acute respiratory syndrome coronavirus 2 (SARS-CoV-2). COVID-19 often begins with respiratory symptoms, such as cough, fever and fatigue, and develops into acute respiratory distress syndrome (ARDS) at the later stages of the disease. However, some patients also exhibit neurological symptoms, including headaches, dizziness, fatigue, a disruption of consciousness, insomnia, anosmia and ischemic stroke $(1,2)$. Ischemic stroke secondary to severe COVID-19 is common and fatal once it appears. Mao et al demonstrated that patients with severe COVID-19 were more likely to have complications with ischemic stroke and this was associated with higher mortality rates (3). Research on the mechanisms through which SARS-CoV-2 induces ischemic stroke has become a popular research topic. It has been demonstrated that SARS-CoV-2 leads to systemic hypercoagulability, namely, to elevated levels of D-dimer and fibrinogen, as the inducing factor of ischemic stroke (4). Consequently, some researchers have postulated that COVID-19 induces ischemic stroke by promoting a hypercoagulable state in affected patients. However, the mechanisms through which COVID-19 induces hypercoagulability remain unclear, and are crucial for the targeted therapy for ischemic stroke induced by COVID-19. The present review summarizes the current 
status of research on COVID-19, hypercoagulability and ischemic stroke. Subsequently, the underlying mechanisms through which COVID-19 induces hypercoagulability are summarized. Moreover, the present review provides therapies that target different mechanisms for different stages of SARS-CoV-2-induced acute ischemic stroke (AIS) and for the prevention of AIS in patients with SARS-CoV-2 infection.

\section{Hypercoagulability and thrombosis in patients with COVID-19}

As the COVID-19 pandemic progresses, there is increasing evidence to indicate that patients with COVID-19 present hypercoagulability and hyperfibrinolysis, particularly those with severe COVID-19; this mainly manifests as increased levels of D-dimer and fibrinogen, a low platelet count, and a prolonged coagulation time (4). Studies have suggested that an increased level of D-dimer in patients with COVID-19 is closely associated with a poor prognosis and a high mortality rate (5), and heparin anticoagulant therapy can effectively reduce the mortality rate of patients with COVID-19 with a D-dimer level $>3.0 \mu \mathrm{g} / \mathrm{ml}$ (6). In addition, the levels of Von Willebrand factor (VWF) and FXIII are considerably increased in patients with COVID-19 (7). Although the level of plasminogen activator inhibitor 1 (PAI-1) in patients with severe COVID-19 has not yet been investigated, it has been found to be increased in patients with severe acute respiratory syndrome; thus, an increased level of PAI-1 would not be unanticipated (8). The coagulation indexes of patients with severe infection exhibit obvious changes compared with those of non-severely infected patients (Table I).

A number of patients with COVID-19 have developed venous and arterial thrombosis, which is often associated with high mortality rates. The autopsy analysis of 12 deceased patients at a research center in Germany revealed that 7 patients had venous thrombosis, and 4 had pulmonary embolism (9). A study from Tongji Hospital revealed $71.4 \%$ of non-survivors had disseminated intravascular coagulation (DIC), while $0.6 \%$ survivors had DIC (5). Xiong et al demonstrated that compared with those in patients with moderate COVID-19, the D-dimer and PT levels were significantly increased in patients with severe COVID-19, suggesting that DIC was common in patients with severe COVID-19 (10). A study on 388 patients demonstrated that 26 had thromboembolic events, including 16 with venous thromboembolism, 10 with pulmonary embolism; in addition, 8 patients had with overt DIC, 9 with ischemic stroke and 4 with myocardial infarction in Italy (11). Further reports of thromboembolic events in patients with COVID-19 are presented in Table II.

\section{COVID-19 and acute ischemic stroke}

AIS during the COVID-19 outbreak remains a disabling and lethal disease that cannot be ignored. The main symptoms of COVID-19 involve fever, cough, and other respiratory symptoms. However, it has been indicated that AIS can also be the primary symptom of COVID-19, which is highly suggested to be induced by SARS-CoV-2 infection (12). As the COVID-19 pandemic progresses, increasing numbers of research groups have focused on the association between
COVID-19 and AIS. Fara et al reported cases of AIS in the early stages of COVID-19 (13). Mao et al demonstrated that $18.7 \%$ of patients with COVID-19 needed to be transferred to the ICU for treatment due to severe neurological symptoms, and $5.7 \%$ of patients with severe COVID-19 had AIS (3). Beyrouti et al analyzed patients with COVID-19 with AIS and found that AIS occurred at 8-24 days following the onset of COVID-19 symptoms; an analysis of the laboratory tests revealed that lactate dehydrogenase, fibrinogen, $\mathrm{D}$-dimer, and C-reactive protein levels were significantly increased in these patients (14). In addition, Li et al found the presence of SARS-CoV-2 in the cerebrospinal fluid of patients, suggesting that this type of virus can penetrate the blood-brain barrier and damage brain tissue (15).

The pathogenesis of AIS includes thrombosis, artery-to-artery embolization and hypoperfusion. However, the pathogenesis of AIS secondary to COVID-19 remains to be investigated. It has been demonstrated that patients with COVID-19 with secondary AIS had an elevated National Institutes of Stroke Scale score at admission, an elevated D-dimer level and a poor prognosis compared to those of non-COVID-19 patients with stroke, suggesting that blood coagulation plays an essential role in AIS secondary to COVID-19 (16). Oxley et al reported cases of secondary AIS in young patients with COVID-19 with elevated levels of D-dimer and fibrinogen, and some of these patients did not have risk factors for stroke, suggesting that COVID-19 induces AIS by promoting hypercoagulability (17). Nevertheless, the exact mechanisms through which COVID-19 induces a hypercoagulable state in patients remain unclear. The following sections focus on possible procoagulant mechanisms of COVID-19. More importantly, therapies that target the specific mechanisms for the more effective treatment of patients with COVID-19 with AIS are discussed.

\section{Mechanisms of hypercoagulability in COVID-19}

Cytokines and hypercoagulability. Previous studies on patients with severe COVID-19 have demonstrated elevated levels of pro-inflammatory cytokines (IL-1, IL-2, IL-6, IL-8, IL-10, IL-17 and TNF- $\alpha)(18,19)$. Elevated levels of cytokines cause inflammation and hypercoagulability in patients with COVID-19, which may be ascribed to several reasons. First, cytokines interact with the coagulation system. Cytokines, such as IL-1, IL-6 and TNF- $\alpha$ facilitate the release of tissue factor (TF), which activates the extrinsic coagulation pathway. Moreover, they promote the expression of PAI-1, which results in the inhibition of the fibrinolysis system (Fig. 1) (20). Beyond that, the levels of TF pathway inhibitors and antithrombin are decreased in an inflammatory environment, which causes the activation of the coagulation system (21). It should be noted that the activation of thrombin can induce the overproduction of pro-inflammatory cytokines through PAR-1, while FXa can activate PAR-1 and PAR-2 to enhance the inflammatory response (22). Second, cytokines interact with NETs. Previous studies have indicated that cytokines promote NET formation, which triggers the extrinsic and intrinsic coagulation pathways, resulting in thrombin generation. Correspondingly, NETs also promote the release of inflammatory cytokines to cause cytokine storms (23). Third, when promoted by IL-1 $\beta$, 
Table I. Comparison of the coagulation indexes between patients with severe COVID-19 and those with non-severe infection.

\begin{tabular}{|c|c|c|c|c|}
\hline Author/(Refs.) & No. of patients & Severe infection & Non-severe infection & P-value \\
\hline \multicolumn{5}{|c|}{ D-dimer (ng/ml) levels } \\
\hline Han et al (4) & $\begin{array}{l}94 \text { (49 ordinary, } \\
35 \text { severe, } 10 \text { critical) }\end{array}$ & $\begin{array}{l}\text { Severe: } 19,110 \pm 35,480 \\
\text { Critical: } 20,040 \pm 32,390\end{array}$ & $2,140 \pm 2,880$ & $\mathrm{P}<0.01$ \\
\hline Tang et al (5) & $\begin{array}{l}183 \text { ( } 21 \text { non-survivors, } \\
162 \text { survivors) }\end{array}$ & $2,120(770-5,270)$ & $610(350-1,290)$ & $\mathrm{P}<0.001$ \\
\hline Fan et al (85) & $\begin{array}{l}73 \text { (47 non-survivors, } \\
26 \text { survivors) }\end{array}$ & $1,510(800-7,180)$ & $520(310-1,120)$ & $\mathrm{P}<0.001$ \\
\hline Zou et al (86) & 303 (35 severe, 277 mild) & $1,040(730-1,720)$ & $430(310-770)$ & $\mathrm{P}<0.001$ \\
\hline Tang et al (58) & $\begin{array}{l}449 \text { (134 non-survivors, } \\
315 \text { survivors) }\end{array}$ & $4,700(1,420-21,000)$ & $1,470(780-4,160)$ & $\mathrm{P}<0.001$ \\
\hline
\end{tabular}

Fibrinogen $(\mathrm{g} / \mathrm{l})$

\begin{tabular}{|c|c|c|c|c|}
\hline Fogarty et al (87) & 83 (50 ICU 33 no ICU) & $5.6(4.4-6.6)$ & $4.5(3.7-6.2)$ & $\mathrm{P}=0.045$ \\
\hline \multirow[t]{2}{*}{ Han et al (4) } & 94 (49 ordinary, & Severe: $4.76 \pm 1.7301$ & $5.10 \pm 1.16$ & $\mathrm{P}<0.01$ \\
\hline & 35 severe, 10 critical) & Critical: $5.59 \pm 2.26$ & & \\
\hline Tang et al (5) & $\begin{array}{l}183 \text { ( } 21 \text { non-survivors, } \\
162 \text { survivors) }\end{array}$ & $5.16(3.74-5.69)$ & $4.51(3.65-5.09)$ & $\mathrm{P}=0.149$ \\
\hline Zou et al (86) & 303 (35 severe, 277 mild) & $4.74(4.21-5.84)$ & $4.33(3.57-5.73)$ & $\mathrm{P}=0.038$ \\
\hline \multicolumn{5}{|c|}{ Prothrombin time (sec) } \\
\hline Tang et al (5) & $\begin{array}{l}183 \text { (21 non-survivors, } \\
162 \text { survivors) }\end{array}$ & $15.5(14.4-16.3)$ & $13.6(13.0-14.3)$ & $\mathrm{P}<0.001$ \\
\hline Fan et al (85) & $\begin{array}{l}73 \text { ( } 47 \text { non-survivors, } \\
26 \text { survivors) }\end{array}$ & $11.80(10.9-12.9)$ & $11.1(10.25-12.05)$ & $\mathrm{P}=0.016$ \\
\hline Zou et al (86) & 303 (35 severe, 277 mild) & $13.8(13.4-14.8)$ & $13.4(13.0-13.8)$ & $\mathrm{P}=0.003$ \\
\hline Tang et al (58) & $\begin{array}{l}449 \text { (134 non-survivors, } \\
315 \text { survivors) }\end{array}$ & $16.5 \pm 8.4$ & $14.6 \pm 2.1$ & $\mathrm{P}<0.001$ \\
\hline
\end{tabular}

Activated partial thromboplastin time (sec)

\begin{tabular}{|c|c|c|c|c|}
\hline Tang et al (5) & $\begin{array}{l}183 \text { (21 non-survivors, } \\
162 \text { survivors) }\end{array}$ & $44.8(40.2-51.0)$ & $41.2(36.9-44.0)$ & $\mathrm{P}=0.096$ \\
\hline Zou et al (86) & 303 (35 severe, 277 mild) & $43.2(41.0-49.7)$ & $39.2(36.3-42.4)$ & $\mathrm{P}<0.001$ \\
\hline Huang et al (88) & 41 (13 ICU, 28 no ICU) & $26.2(22.5-33.9)$ & $27.7(24.8-34.1)$ & $\mathrm{P}=0.57$ \\
\hline \multirow[t]{2}{*}{ Wu et al (89) } & $\begin{array}{l}201 \text { (117 no ARDS, } \\
84 \text { ARDS) }\end{array}$ & $26(22.55-35)$ & $29.75(25.55-32.85)$ & $\mathrm{P}=0.130$ \\
\hline & $\begin{array}{l}84 \text { (40 ARDS alive, } \\
44 \text { ARDS died) }\end{array}$ & $24.10(22.55-8.35)$ & $29.60(24-35.75)$ & $\mathrm{P}=0.040$ \\
\hline
\end{tabular}

Platelet count $\left(\times 10^{9}\right.$ per 1$)$

\begin{tabular}{lllr}
\hline Fan et al $(85)$ & 73 (47 non-survivors, & $168(136-221)$ & $204(149-268)$ \\
& 26 survivors) & & $231 \pm 99$ \\
Tang et al $(58)$ & $449(134$ non-survivors, & $178 \pm 92$ & $\mathrm{P}=0.054$ \\
& 315 survivors $)$ & & $149(131-263)$ \\
Huang et al $(88)$ & $41(13$ ICU, 28 no ICU) & $196(165-263)$ & $178(140-239.50)$ \\
Wu et al $(89)$ & $201(117$ no ARDS & $187(124.50-252.50)$ & $\mathrm{P}=0.45$ \\
& 84 ARDS $)$ & & $204(137.25-262.75)$ \\
& $84(40$ ARDS alive, & $162(110.5-231)$ & $P=0.73$ \\
& 44 ARDS died) & &
\end{tabular}


Table I. Continued.

\begin{tabular}{|c|c|c|c|c|}
\hline Author/(Refs.) & No. of patients & Severe infection & Non-severe infection & P-value \\
\hline \multicolumn{5}{|c|}{ Fibrinogen degradation products (mg/l) } \\
\hline Han et al (4) & $\begin{array}{l}94 \text { (49 ordinary, } \\
35 \text { severe, } 10 \text { critical) }\end{array}$ & $\begin{array}{l}\text { Severe: } 60.01 \pm 108.98 \\
\text { Critical: } 69.15 \pm 129.19\end{array}$ & $7.92 \pm 11.38$ & $\mathrm{P}<0.01$ \\
\hline Tang et al (5) & $\begin{array}{l}183 \text { (21 non-survivors, } \\
162 \text { survivors) }\end{array}$ & $7.6(4.0-23.4)$ & $4.0(4.0-4.3)$ & $\mathrm{P}<0.001$ \\
\hline Zou et al (86) & 303 (26 severe, 277 mild) & $2.61(1.44-4.48)$ & $0.99(0.52-1.98)$ & $\mathrm{P}<0.001$ \\
\hline
\end{tabular}

ICU, intensive care unit; ARDS, acute respiratory distress syndrome.

Table II. Thromboembolic events in patients with COVID-19.

\begin{tabular}{|c|c|c|c|}
\hline Author/(Refs.) & Patients & Thromboembolic events & Other findings \\
\hline Cui et al (90) & 81 & VTE $(25 \%)$ & Elevated D-dimer was a good index to recognize VTE. \\
\hline Stoneham et al (91) & 274 & VTE $(7.7 \%)$ & $\begin{array}{l}\text { Levels of D-dimer were higher in patients with VTE than those } \\
\text { without VTE. }\end{array}$ \\
\hline Helms et al (7) & 150 & PE $(16.7 \%)$ & $\begin{array}{l}\text { Compared with non-COVID-19 ARDS patients, patients with } \\
\text { COVID-19 ARDS were more prone to PE. }\end{array}$ \\
\hline $\begin{array}{l}\text { Léonard-Lorant } \\
\text { et al }(92)\end{array}$ & 106 & PE $(30 \%)$ & $\begin{array}{l}\text { D-dimer levels }>2,660(\mathrm{ng} / \mathrm{ml}) \text { indicated PE. The sensitivity was } \\
100 \% \text { and the specificity was } 67 \% \text {. }\end{array}$ \\
\hline Llitjos et al (93) & 26 & VTE $(69 \%)$, PE $(23 \%)$ & $\begin{array}{l}\text { COVID-19 patients treated with therapeutic anticoagulation were } \\
\text { more prone to VTE and PE. }\end{array}$ \\
\hline Tang et al (5) & 183 & $\operatorname{DIC}(8.7 \%)$ & $\begin{array}{l}71.4 \% \text { of non-survivors combined with DIC while } 0.6 \% \text { of } \\
\text { survivors combined with DIC. }\end{array}$ \\
\hline Mao et al (3) & 214 & AIS $(5.7 \%)$ & $\begin{array}{l}\text { Patients with Severe COVID-19 were more likely to have } \\
\text { neurologic manifestations, such as acute cerebrovascular diseases. }\end{array}$ \\
\hline Beyrouti et al (14) & 6 & AIS & AIS occurred 8-24 days after the symptom onset of COVID-19. \\
\hline Poillon et al (94) & 2 & CVT & $\begin{array}{l}\text { Some COVID-19 patients exhibit neurological complications } \\
\text { including CVT. }\end{array}$ \\
\hline Klok et al (60) & 184 & VTE $(27 \%)$, AIS (3.7\%) & $\begin{array}{l}\text { PT }>3 \mathrm{sec} \text { or APTT }>5 \mathrm{sec} \text { were independent predictors of } \\
\text { thromboembolic events. }\end{array}$ \\
\hline Lodigiani et al (11) & 362 & $\begin{array}{c}\text { VTE }(4.4 \%), \operatorname{PE~}(2.7 \%) \\
\text { AIS }(2.5 \%), \text { ACS/MI }(1.1 \%)\end{array}$ & $\begin{array}{l}\text { Half of thromboembolic events were diagnosed within } 24 \mathrm{~h} \\
\text { after hospitalization. }\end{array}$ \\
\hline
\end{tabular}

VTE, venous thromboembolism; PE, pulmonary embolism; DIC, disseminated intravascular coagulation; AIS, acute ischemic stroke; CVT, cerebral venous thrombosis; ACS, acute coronary syndrome; MI, myocardial infarction; PT, prothrombin time; APTT, activated partial thromboplastin time.

IL-8 and TNF- $\alpha$, blood cells (erythrocytes, leukocytes, and lymphocytes) expose phosphatidylserine (PS) to their outer membrane, which leads to a hypercoagulable state (24). In summary, it is inferred that the elevated levels of cytokines in COVID-19 patients and the subsequent activation of the coagulation system leads to AIS.

Endothelial cell injury and hypercoagulability. Varga et al found viral particles in endothelial cells of renal tissue, intestinal tissue, and lung tissue of patients with COVID-19, suggesting that SARS-CoV-2 invades endothelial cells in multiple tissues and organs (25). Similarly, Leisman et al found that SARS-CoV-2 can invade endothelial cells through the angiotensin-converting enzyme 2 (ACE2) receptor, leading to tissue damage and cytokine disruption (26). Additionally, cytokine storms of COVID-19 can also damage endothelial cells. Endothelial cells express TF and PS under the stimulation of cytokines or NETs (27). The former initiates the extrinsic pathway of coagulation, while the latter can provide a catalytic surface for coagulation factors and promote intrinsic and extrinsic FXa and thrombin production. In addition, damaged endothelial cells can express VWF, which interacts with platelets to promote thrombosis. Damaged endothelial cells also release PAI-1, which inhibits the fibrinolytic 


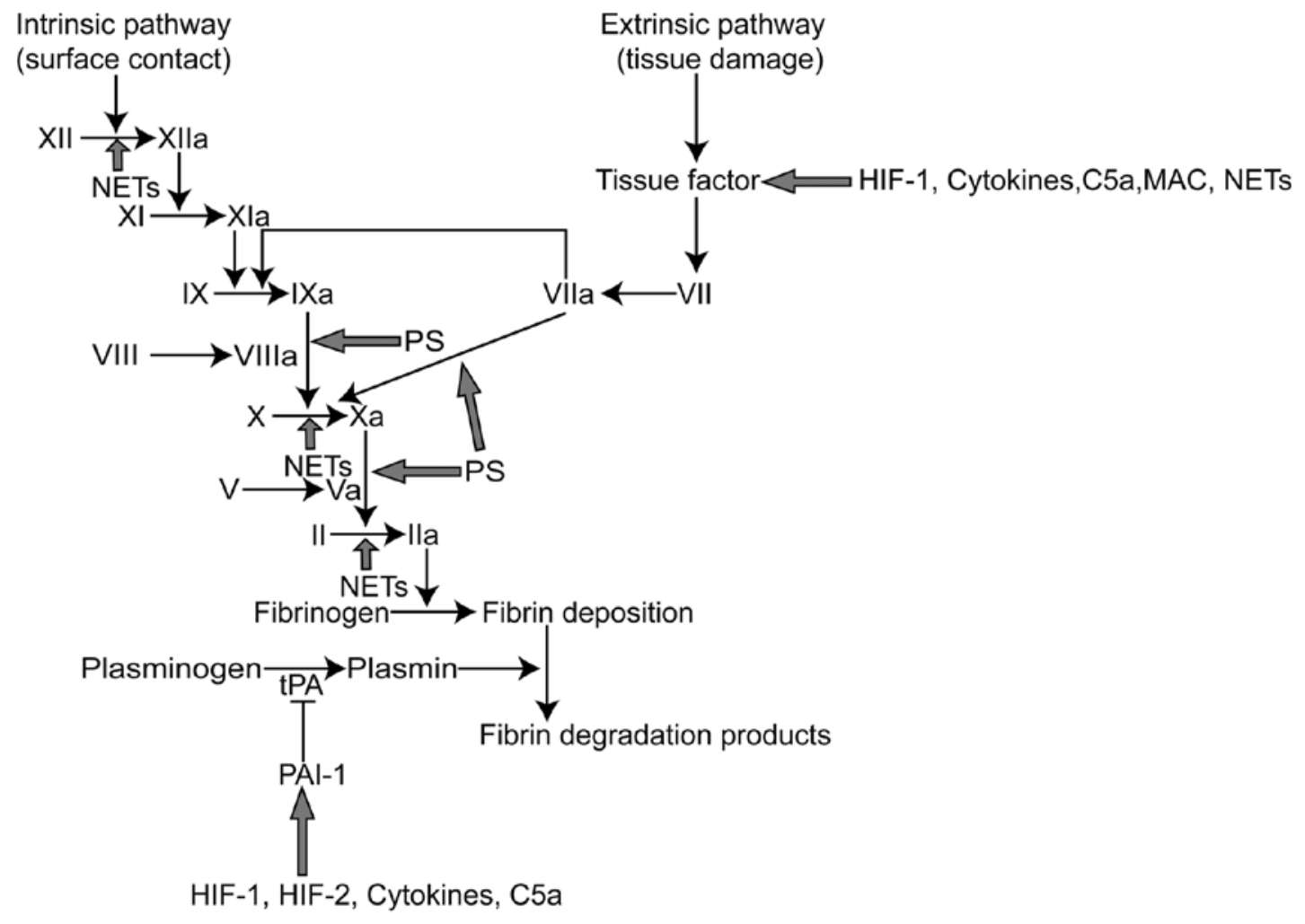

Figure 1. HIFs, cytokines, NETs, phosphatidylserine and the complement system promote coagulation. HIF-1, cytokines, C5a, MAC and NETs increase the expression of tissue factor, which activates extrinsic blood coagulation, while HIF-1, HIF-2, cytokines and C5a promote the expression of PAI-1, which impairs fibrinolysis. Cell membrane phosphatidylserine can provide a catalytic surface for coagulation factors, promoting intrinsic and extrinsic FXa and thrombin production. NETs promote XIIa, intrinsic FXa, and thrombin production. HIF-1, hypoxia inducible factor -1; HIF-2, hypoxia inducible factor -2; PS, phosphatidylserine; PAI-1, plasminogen activator inhibitor 1; tPA, tissue plasminogen activator; NETs, neutrophil extracellular traps; MAC, membrane attack complex.

system and results in thrombosis. Previous studies $(28,29)$ have demonstrated that damaged endothelial cells are closely related to AIS. More importantly, brain neurons, endothelial cells and vascular smooth muscle cells express the ACE2 receptor, which enables SARS-CoV-2 to cross the blood-brain barrier, leading to damage of the central nervous system $(28,29)$. In summary, SARS-CoV-2 may cause damage to brain endothelial cells and induce local hypercoagulability to promote cerebral thrombosis.

Platelet activation and hypercoagulability. The majority of patients with severe COVID-19 have abnormal laboratory data, including low platelet and lymphocyte counts and increased levels of neutrophils, D-dimer and C-reactive protein (30). Among these, a low platelet count has attracted increasing attention. $\mathrm{Xu}$ et al hypothesized that there were 3 main reasons for platelet reduction: First, viruses may cause decreased platelet synthesis; second, viruses may lead to increased platelet destruction; and third, viruses may contribute to thrombosis, which results in platelet consumption (31). Although platelet counts are reduced in patients with COVID-19, platelets are actually activated as reduced platelets are used to form microthrombi, which may adhere to the endothelium of blood vessels damaged by the virus (32). Thus, it is reasonable to believe that activated platelets promote hypercoagulability. On the one hand, activated platelets release microparticles (MPs), VWF and PAI to promote coagulation (27), and promote the generation of NETs that participate in the formation of hypercoagulability (33). Moreover, platelet activation is a prominent feature of AIS. Therefore, platelet activation in patients with COVID-19 may promote hypercoagulability and induce AIS.

Neutrophil extracellular traps and hypercoagulability. Under inflammatory conditions, neutrophils catch bacteria by extruding neutrophil extracellular traps (NETs), which are composed of DNA, histones and other active proteins (34). However, NETs are associated with hypercoagulable states of disease and even promote thrombosis (Fig. 1) (35). Patients with COVID-19 are in a state of inflammation, which is advantageous for the generation of NETs. Some patients with COVID-19 already have elevated neutrophil counts (14). Moreover, the inflammatory response triggered by excessive NET formation is directly related to the destruction of surrounding tissues and microthrombosis and plays an important role in organ damage. The above 3 points have been proven to be essential causes of multiorgan failure in patients with severe COVID-19 (36). Zuo et al found that the plasma levels of cell free DNA (cf-DNA), myeloperoxidase (MPO)-DNA and citrullinated histone $\mathrm{H} 3$ (CitH3) were significantly elevated in patients with COVID-19, thereby confirming the presence of NETs in these patients (37). Their study also found that plasma cf-DNA levels were positively associated with plasma D-dimer levels, suggesting that NETs were associated with hypercoagulability in patients (37). Previous research has demonstrated the presence of NETs in thrombi and the 

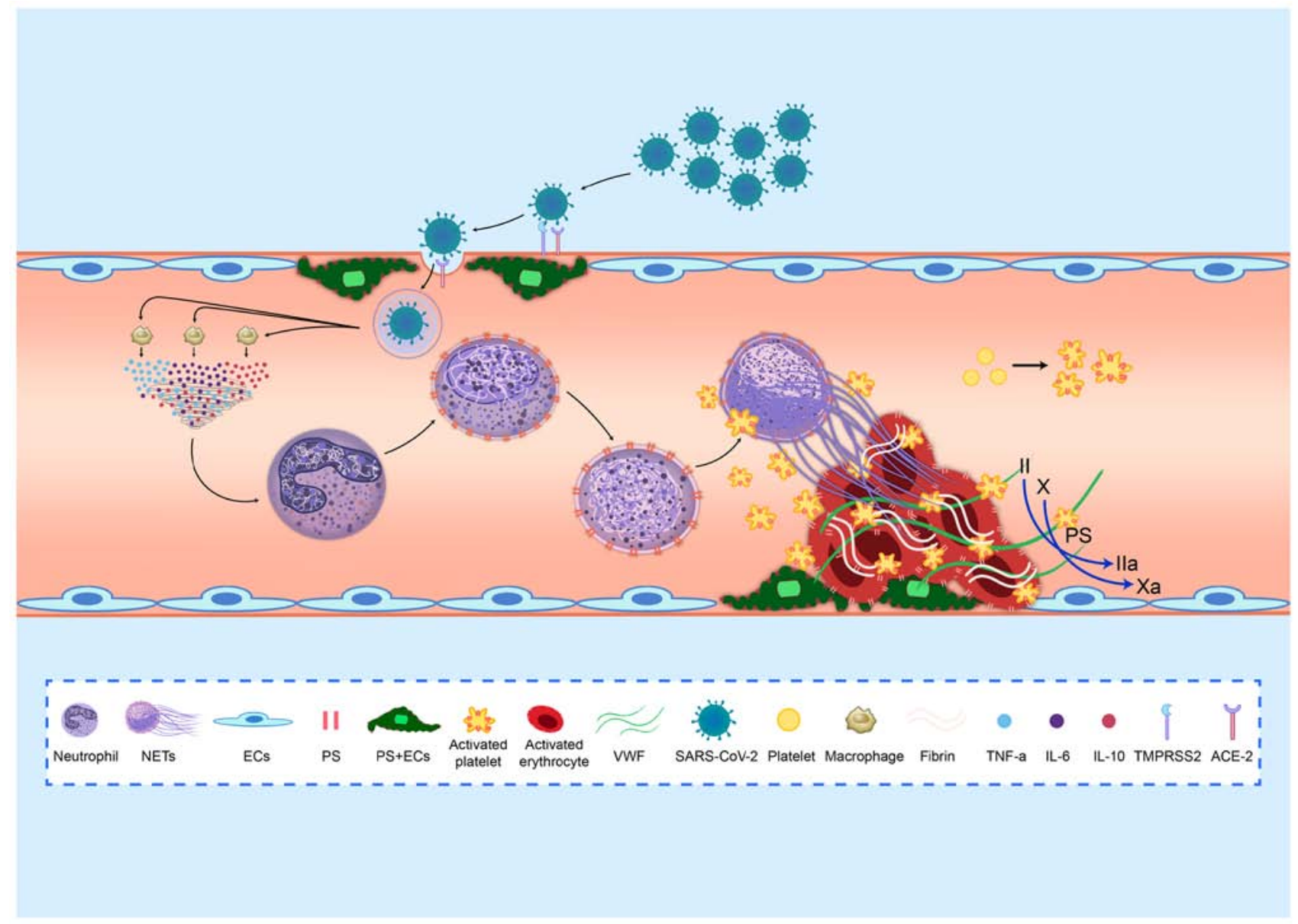

Figure 2. NETs contribute to SARS-CoV-2-induced acute ischemic stroke by activating endothelial cells and platelets. SARS-CoV-2 enters blood vessels through the ACE2 receptor on cerebrovascular endothelial cells. The virus activates neutrophils to release NETs through a cytokine storm derived from activated macrophages. NETs initiate thrombosis by activating endothelial cells and platelets. NETs, neutrophil extracellular traps; SARS-CoV-2, severe acute respiratory syndrome coronavirus 2 .

peripheral blood of patients with AIS, and the NET content in peripheral blood is associated with the hypercoagulability of patients with AIS (33). Based on the above-mentioned studies, it can be hypothesized that NETs in patients with COVID-19 lead to a hypercoagulable state that induces AIS (Fig. 2).

MPs and hypercoagulability. MPs are vesicles (100-1,000 nm) in diameter derived from the shedding of the cellular membrane of activated or apoptotic cells. Circulating MPs are produced by a variety of cells, such as erythrocytes, granulocytes, monocytes, platelets, and endothelial cells (38). In recent years, studies have found that MPs induce hypercoagulability in a number of diseases, such as sepsis, stroke and nephrotic syndrome $(39,40)$. The expression of phosphatidylserine (PS) is the underlying cause of MP-induced coagulation. Cell membrane PS can provide a catalytic surface for coagulation factors, promoting intrinsic and extrinsic FXa and thrombin production (Fig. 1) (41). In addition, Wang et al found that neutrophil extracellular trap-MP complexes can promote the intrinsic pathway of coagulation in a sepsis mouse model; they subsequently found that neutrophil extracellular trap-MP complexes can trigger inflammation by mediating neutrophil aggregation through HMGB1-TLR2/TLR4 signaling $(42,43)$. Damaged endothelial cells and epithelial cells are also found to release MPs in a number of respiratory diseases, such as chronic obstructive pulmonary disease, asthma, pulmonary fibrosis and pulmonary hypertension (44). However, whether MPs play roles in COVID-19 has not yet been determined. Previous research has indicated that the systemic inflammatory response syndrome leads to the activation or apoptosis of blood cells throughout the body, resulting in the production of MPs (45). Systemic inflammatory response syndrome is the main cause of multiple organ failure in patients with severe COVID-19 (19). Therefore, there is reason to believe that MPs play a procoagulant role in patients with severe COVID-19.

Complement activation and hypercoagulability. The complement system plays a major role in regulating the immune system to protect against viruses. However, inadequate complement activation may also cause a systemic inflammatory response that leads to tissue damage. In addition, complement activation is also associated with coagulation and microthrombosis (Fig. 1). Complement activation contributes to membrane attack complex formation, which drives neutrophil activation and endothelial damage (46). Cugno et al demonstrated that the plasma levels of C5a and sC5b-9 were significantly higher in patients with COVID-19 compared with healthy subjects, suggesting the activation of the complement system in patients with COVID-19 (47). Magro et al suggested that complement system activation was associated with 
thrombosis in patients with severe COVID-19 (48). Complement activation may be caused by the following 2 mechanisms (49): i) The antigen-antibody complexes formed by antibodies combined with viral antigens initiate complement activation; and ii) viral invasion results in damage to endothelial cells, which leads to the activation of the complement system. Strategies targeting the complement system have been exert protective effects against brain ischemia-reperfusion injury, indirectly reflecting that complement activation plays an important role in the development of AIS (50). Therefore, it is feasible to believe that the activation of the complement system in COVID-19 contributes to hypercoagulability, which induces AIS.

Hypoxia and hypercoagulability. ARDS, the most common symptom of patients with severe COVID-19, contributes to hypoxia in the entire body, playing an essential role in regulating thrombosis by triggering a number of molecular signaling pathways (51). Platelets are more likely to be activated in low oxygen environments (52). Moreover, hypoxia prompts the generation of hypoxia inducible factor (HIF)-1 and HIF-2, leading to the activation of the coagulation system and impairment of the fibrinolysis system. More precisely, HIF-1 $\alpha$ increases the expression of TF, which activates extrinsic blood coagulation, while HIF-1 and HIF-2 promote the expression of PAI-1, which impairs fibrinolysis (Fig. 1) (53). Additionally, HIF-1 $\alpha$ induces the formation of NETs (54). NET formation released by activated neutrophils promotes a hypercoagulable state in the circulation.

Antiphospholipid antibody and hypercoagulability. It has previously been reported that bacteria or viruses can induce antiphospholipid antibodies. A recent article in the New England Journal of Medicine demonstrated that antiphospholipid antibody in patients with COVID-19 was associated with hypercoagulability and the onset of AIS (55). Although only 3 patients were discussed in that article, sufficient attention should be paid. Subsequently, Beyrouti et al also found that patients with COVID-19 with AIS had positive antiphospholipid antibodies, which were suspected to be related to the onset of stroke (14). It has been demonstrated that antiphospholipid antibodies initiate coagulation by activating the TF signaling pathway (56). It has also been proven that positive antiphospholipid antibodies are a risk factor for AIS (57). Therefore, it is considered that the antiphospholipid antibody in COVID-19 activates the coagulation system and contributes to the onset of AIS. However, there are no drugs that target antiphospholipid antibodies in COVID-19. Further research into this matter is required in the future.

\section{Antithrombotic therapy for COVID-19}

Traditional antithrombotic therapy for COVID-19 with coagulopathy. Currently, traditional antithrombotic treatments for COVID-19 with coagulopathy include anticoagulant therapy and thrombolytic therapy. Heparin, an anticoagulant and anti-inflammatory drug, has been used in the treatment of the hypercoagulable state of COVID-19. Tang et al demonstrated that COVID-19-induced mortality was reduced by heparin treatment (58). Compared with heparin, low molecular weight heparin (LMWH) has a long half-life, is associated with less bleeding and there is no need for routine coagulation monitoring. Oudkerk et al suggested that patients with COVID-19 should be treated with prophylactic LMWH as soon as they are admitted to the hospital (59). Klok et al found that despite the prevention of systemic thrombosis with a low dose of LMWH, a number of patients with COVID-19 still developed thrombotic events; therefore, a high dose of LMWH was recommended for anticoagulation in patients with COVID-19 admitted to the ICU (60). However, has not been determined which dose of LMWH should be used and this remains controversial. A previous study found that $31.6 \%$ of subjects supported an intermediate dose for moderate or severe COVID-19, while $5.2 \%$ of subjects supported a therapeutic dose, and the rest supported a prophylactic dose (61). New oral anticoagulants were also recommended during the COVID-19 pandemic due to their safety, convenience, and strong anticoagulant effects (62). SARS-CoV-2 infection not only activates the coagulation system but also inhibits the fibrinolytic system. Tissue plasminogen activator (tPA), a thrombolytic drug for AIS, has been reported to be effective for COVID-19 patients complicated with ARDS (63). However, the risk of bleeding should also be evaluated. In addition, chloroquine, which has been widely used in the treatment of COVID-19, can also play an antithrombotic role by inhibiting NETs and interfering with platelet aggregation (64). Statins can prevent the virus from infecting cells and inhibit the inflammatory response and coagulation activation, so they could be used to treat thrombosis in patients with COVID-19 (65). Further information on the antithrombotic therapy of COVID-19 is presented in Table III. In addition, some recommendations for antithrombotic therapy are presented in Table IV. Although anticoagulant therapy and thrombolytic therapy have been shown to be effective, a number of patients with COVID-19 develop thrombotic complications. Therefore, it is necessary to explore novel methods of antithrombotic therapy. Below, antithrombotic therapy targeting different mechanisms for coagulation is discussed.

Targeted therapy against cytokines. Considering the crucial role of cytokines in leading to tissue damage and a hypercoagulable state, targeting cytokines in patients with COVID-19 has become an inevitable trend. It has been proven that IL- 6 initiates the inflammatory response in patients with COVID-19. Tocilizumab, sarilumab and siltuximab, as inhibitors of IL-6 and its receptor, have been approved by the Food and Drug Administration for the treatment of rheumatic and lymphoproliferative diseases. Importantly, tocilizumab has been approved for the treatment of patients with COVID-19 with elevated levels of IL-6 $(66,67)$. IL-17, which acts upstream of IL-1 $\beta$, IL- 6 and TNF- $\alpha$, should attract increasing attention. Secukinumab, ixekizumab and brodalumab, as inhibitors of IL-17 and its receptor, have been shown to be effective in the treatment of psoriasis (18); however, their effects on COVID-19 need to be further investigated.

Therapy for the protection of endothelial cells. Preventing viruses from entering cells has become a novel method for the treatment of COVID-19. Human recombinant soluble angiotensin-converting enzyme 2 (hrsACE2), currently being studied, can competitively bind to viruses to inhibit viruses from being able to invade into cells (68). Fortunately, hrsACE2 
Table III. Antithrombotic therapy for COVID-19.

\begin{tabular}{|c|c|c|c|}
\hline Author/(Refs.) & Drug & No. of patients & Main findings \\
\hline Paranjpe et al (95) & - & 2,733 & $\begin{array}{l}\text { Compared with patients who did not receive AC, patients treated } \\
\text { with AC had lower mortality and longer survival time. }\end{array}$ \\
\hline Paranjpe et al (95) & - & 395 & $\begin{array}{l}\text { Compared with patients who only receive mechanical ventilation, } \\
\text { patients treated with both mechanical ventilation and AC had } \\
\text { lower mortality and longer survival time. }\end{array}$ \\
\hline Tang et al (58) & LMWH & 449 & $\begin{array}{l}\text { There was a lower mortality in COVID- } 19 \text { patients with D-dimer } \\
>3 \mu \mathrm{g} / \mathrm{ml} \text { treated with heparin than those who did not receive } \\
\text { heparin. }\end{array}$ \\
\hline Wang et al (63) & $\mathrm{tPA}$ & 3 & $\begin{array}{l}\text { P/F ratio was significantly improved in COVID- } 19 \text { patients with } \\
\text { ARDS after administration of tPA. }\end{array}$ \\
\hline White et al (96) & $\begin{array}{l}\text { LMWH } \\
\text { heparin }\end{array}$ & 69 & $\begin{array}{l}\text { Evidence of heparin resistance exists in severe COVID-19 patients, } \\
\text { which might lead to anticoagulation treatment failure. }\end{array}$ \\
\hline Arachchillage et al (97) & Argatroban & 10 & $\begin{array}{l}\text { Argatroban can be used to treat COVID- } 19 \text { patients with thrombosis } \\
\text { who have heparin resistance due to reduced antithrombin levels. }\end{array}$ \\
\hline Ranucci et al (98) & LMWH & 16 & $\begin{array}{l}\text { Fibrinogen and d-dimer were significantly decreased in patients } \\
\text { treated with low molecular weight heparin. }\end{array}$ \\
\hline
\end{tabular}

$\mathrm{AC}$, systemic anticoagulation; LMWH, low molecular weight heparin; tPA, tissue plasminogen activator; $\mathrm{P} / \mathrm{F}$ ratio, $\mathrm{PaO}_{2} / \mathrm{FiO}_{2}$ ratio; '-' indicates data are not available.

has been approved for the treatment of ARDS (68-70). Given the damage exerted by cytokines to endothelial cells, anti-inflammatory treatment such as with tocilizumab may also protect endothelial cells $(18,66)$. Additionally, colchicine, azithromycin and famotidine have also been proven to reduce endothelial injury (71).

Targeted therapy against platelets. Previous studies have demonstrated that aspirin is effective in patients with pneumonia, particularly in those with severe pneumonia complicated by ARDS or sepsis (72). In animal experiments, the combination of clopidogrel and oseltamivir has been shown to effectively inhibit the inflammatory response induced by influenza pneumonia and can thus improve the survival rate of mice (73). Furthermore, aspirin and clopidogrel can efficiently prevent the occurrence of cardiovascular and cerebrovascular diseases.

Targeted therapy against NETs. The targeting of NETs for the treatment of inflammatory diseases and thrombotic diseases has improved. Thus, there is reason to believe that therapies that target NETs are of vital importance for COVID-19 treatment. Currently, there are 3 main mechanisms against NETs: The inhibition of NET formation, the direct degradation of NETs and the inhibition of upstream regulatory molecules of NETs. The histone inhibitor, activated protein $\mathrm{C}$ and the neutrophil elastase inhibitor, sivelestat, have been shown to reduce hypercoagulability in AIS by inhibiting the generation of NETs (33). BWA3, an anti-histone H4 antibody, can effectively reduce infarct size in t-MACO mice (74). Recombinant DNase I (dornase alfa) can directly degrade NETs in the airway of patients with cystic fibrosis, relieving patient symptoms (75). In addition, recombinant DNase I has been shown to improve the efficiency of tPA thrombolysis in vitro (76) and reduced hypercoagulability in patients with AIS (33). IL-1 $\beta$ and HMGB1 have been reported to mediate the generation of NETs in various diseases. Targeting IL-1 $\beta$ or HMGB1 can inhibit the generation of NETs, thereby improving multiorgan functions $(77,78)$.

Targeted therapy against MPs. Lactadherin can inhibit the expression of PS on MPs both in vivo and in vitro and has been shown to effectively prevent hypercoagulability in disease $(39,40)$. Tiotropium is a muscarinic antagonist that inhibits the release of MPs from bronchial epithelial and endothelial cells, thereby reducing the risk of acute exacerbations of chronic obstructive pulmonary disease (79). Pirfenidone has been proven effective for the treatment of idiopathic fibrosis by inhibiting the p38-mediated formation of procoagulant MPs (80). However, whether lactadherin, tiotropium and pirfenidone can be used in the treatment of patients with severe COVID-19 warrants further investigation.

Targeted therapy against complement activation. The inhibition of the complement system may be an underlying treatment for patients with severe COVID-19 with coagulopathy. In a virus-infected mouse model, the inhibition of C3 or C5 was shown to reduce the inflammatory response by attenuating the release of cytokines (81). The C5 inhibitor eculizumab may treat COVID-19 by hampering the amplification of the complement cascade (47). The C3 inhibitor, AMY-101, which can effectively inhibit the production of $\mathrm{C} 3 \mathrm{a}$ and $\mathrm{C} 5 \mathrm{a}$ and inhibit the release of IL-6, is currently undergoing clinical trials for the treatment of periodontal disease (NCT03694444) (82).

Targeted therapy against hypoxia. Mechanical ventilation is a key treatment for patients with severe COVID-19 with ARDS. 
Table IV. Recommendations for antithrombotic therapy.

Author/(Refs.)

Recommendation for anticoagulant therapy

Thachil et al (99) ISTH: Patients admitted to hospital for COVID-19 have no contraindications (hemorrhage or platelet count $<25 \times 10^{9} / 1$ ) should receive prophylactic LMWH.

Sardu et al (71) In absence of contraindications, enoxaparin $40 \mathrm{mg} / \mathrm{day}$ is recommended for all patients; enoxaparin $1 \mathrm{mg} / \mathrm{kg}$ every $12 \mathrm{~h}$ is recommended for those with D-dimer levels $>3 \mu \mathrm{g} / \mathrm{ml}$.

Connors and

Levy (100)

For obese patients, UFH $7 \mathrm{~m} 500$ units 3 times a day or $40 \mathrm{mg}$ enoxaparin twice a day are recommended.

Klok et al (60) Given the short half-life and strong ability to be administered parenterally, LMWH or UFH should be administered to critically ill patients instead of giving direct oral anticoagulants.

\section{COVID-19 patients admitted to the ICU.}

Thachil et al (101) Oral anticoagulants should be used with caution in patients with kidney function deficiency and those taking anti-retroviral drugs.

Oudkerk et al (59) For patients with D-dimer levels $<1,000(\mathrm{ng} / \mathrm{ml})$, prophylactic anticoagulation is recommended. For patients with D-dimer $>1,000(\mathrm{ng} / \mathrm{ml})$ and D-dimer levels increase progressively, therapeutic anticoagulation is recommended.

Bikdeli et al (102) All hospitalized COVID-19 patients should be evaluated the risk of VTE. In absence of contraindications, all patients should receive prophylactic anticoagulation.

All discharged patients should be evaluated the risk of VTE. Patients at risk of VTE should be given prophylactic anticoagulation for 45 days unless thereis a risk of bleeding.

The interaction between antithrombotic drugs and routine COVID-19 drugs should be considered.

The hepatic and renal function, and certain complications, such as DIC and hemorrhage, should be taken into account when undergoing antithrombotic therapy.

ISTH, International Society on Thrombosis and Hemostasis; LMWH, low molecular weight heparin; UFH, unfractionated heparin; DIC, disseminated intravascular coagulation.

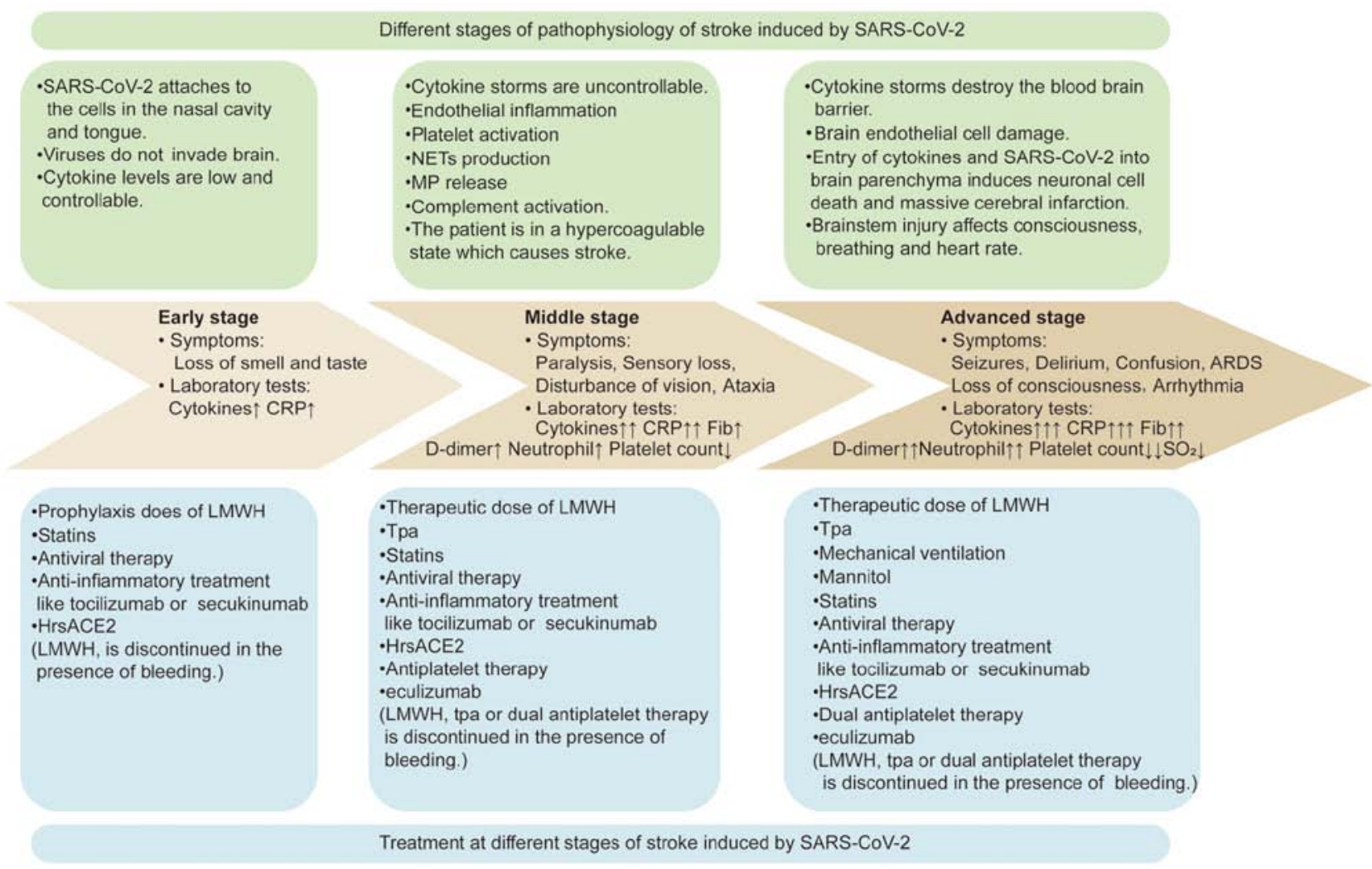

Figure 3. Antithrombotic strategies for different stages of COVID-19-associated acute ischemic stroke. SARS-CoV-2, severe acute respiratory syndrome coronavirus 2; NETs, neutrophil extracellular traps; MPs, microparticles; CRP, C-reactive protein; Fib, fibrinogen; ARDS, acute respiratory distress syndrome; SO2, oxygen saturation of hemoglobin; LMWH, low molecular weight heparin; tPA, tissue plasminogen activator; HrsACE2, human recombinant soluble angiotensin-converting enzyme 2 . 
Table V. Methods for the prevention of acute ischemic stroke.

Population in question

General population without risk of COVID-19

Asymptomatic patients screened positive for SARS-CoV-2

COVID-19 patients being managed at the outpatient clinic

COVID-19 patients

admitted to hospital in non-ICU setting

Severe COVID-19

patients requiring ICU

Discharged COVID-19 patients

Current recommendation

Potential drugs for research

Regular physical activity, consumption of sufficient water/liquids, low-fat diet, low-salt diet

No prophylaxis, regular physical activity, consumption of sufficient water/liquids, low-fat diet, low-salt diet

Individual risk assessment for AIS, regular physical activity, consumption of sufficient water/liquids, low-fat diet, low-salt diet

Prophylactic LMWH if not contraindicated, consumption of sufficient water/liquids, low-fat diet, low-salt diet

Prophylactic LMWH if not contraindicated

Individual risk assessment for AIS, prophylactic anticoagulation for 45 days if not contraindicated, regular physical activity, consumption of sufficient water/liquids, low-fat diet, low-salt diet
None

DOACs, aspirin, clopidogrel

DOACs, aspirin, clopidogrel

DOACs, aspirin, clopidogrel, Tpa, tocilizumab, dornase alfa, pirfenidone, tiotropium, colchicine, eculizumab, HrsACE2

Tpa, tocilizumab, dornase alfa, pirfenidone, tiotropium, colchicine, eculizumab, HrsACE2

DOACs, aspirin, clopidogrel

SARS-CoV-2, acute respiratory syndrome coronavirus 2; DOAC, direct oral anticoagulant; AIS, acute ischemic stroke; LMWH, low molecular weight heparin; Tpa, tissue plasminogen activator; ICU, intensive care unit; HrsACE2, human recombinant soluble angiotensin-converting enzyme 2 .

Hyperbaric oxygen therapy has been shown to improve neurological function in patients with stroke (83). Extracorporeal membrane oxygenation has been used in the treatment of COVID-19-related ARDS (84). However, whether oxygen therapy or extracorporeal membrane oxygenation is effective for COVID-19 patients with AIS needs to be studied further.

Antithrombotic strategies for different stages of SARS-CoV-2-induced AIS. SARS-CoV-2-induced AIS encompasses 3 main stages: An early stage that involves controllable levels of cytokines with mild symptoms, a middle stage that is characterized by the activation of the coagulation system and occurrence of AIS, and an advanced stage that involves the progression to massive cerebral infarction. The present review summarized the pathophysiology, symptoms and laboratory tests at different stages of SARS-CoV-2-induced AIS. More importantly, antithrombotic strategies are suggested for different stages of SARS-CoV-2-induced AIS (Fig. 3).

\section{Prevention of acute ischemic stroke}

Various methods are proposed for the prevention of AIS according to the different states of patients with SARS-CoV-2 infection (Table V).

\section{Conclusions and future perspectives}

Although various components, including cytokines, damaged endothelial cells, activated platelets, NETs, MPs, the activated complement system, hypoxia and the antiphospholipid antibody, are believed to activate the coagulation system during the development of COVID-19, it is considered that cytokines play a predominant role in COVID-19-associated hypercoagulability. The invasion of SARS-CoV-2 activates the immune system and produces a large number of cytokines. Cytokines and the invasion of SARS-CoV-2 result in the injury of endothelial cells, which then leads to the generation of NETs, the release of MPs, the activation of platelets and the activation of the complement system. Given that brain tissue is highly sensitive to hypoxia, hypoxia plays an essential role in COVID-19-associated stroke. Hypoxia can not only lead to brain interstitial edema but also activate the coagulation system.

Antithrombotic therapy is often overlooked in the treatment of COVID-19. Antithrombotic therapy can not only treat thrombosis in COVID-19 but can also increase the blood oxygen saturation level in patients with COVID-19. However, traditional antithrombotic therapy fails to treat COVID-19 with coagulopathy. A more comprehensive antithrombotic therapy targeting different mechanisms should be given to COVID-19 patients who develop thrombosis, such as stroke. We believe that traditional antithrombotic therapy plus anti-inflammatory therapy should be used as the basis of comprehensive antithrombotic therapy.

The present review focused on the mechanisms that lead to the hypercoagulable state in patients with COVID-19 and the association between AIS and these mechanisms. A more comprehensive treatment method was also provided to 
complement traditional antithrombotic therapy. In addition, methods for the prevention of AIS were discussed. Since patients with severe COVID-19 are prone to complications with AIS, antithrombotic therapy should be given in the early stages of COVID-19 to prevent the occurrence of AIS.

\section{Acknowledgements}

Not applicable.

\section{Funding}

The present study was supported by grants from the National Science Foundation of China (81670128 and 81873433) and the Graduate Innovation Fund of Harbin Medical University (YJSSJCX2019-07HYD).

\section{Availability of data and materials}

Not applicable.

\section{Authors' contributions}

SZ designed the review, prepared the tables and figures, and wrote the manuscript. JZ and $\mathrm{XC}$ were involved in the conception and design of the study. CW and XZ searched the literature and wrote the manuscript. HJ, HL and ZL provided helpful comments and acquired data. LW was involved in the conception and design of the study and revised the manuscript. JS designed the study and revised the manuscript. All authors read and approved the final manuscript.

\section{Ethics approval and consent to participate}

Not applicable.

\section{Patient consent for publication}

Not applicable.

\section{Competing interests}

The authors declare that they have no competing interests.

\section{References}

1. Jamwal S, Gautam A, Elsworth J, Kumar M, Chawla R and Kumar P: An updated insight into the molecular pathogenesis, secondary complications and potential therapeutics of COVID-19 pandemic. Life Sci 257: 118105, 2020.

2. Nalleballe K, Reddy Onteddu S, Sharma R, Dandu V, Brown A, Jasti M, Yadala S, Veerapaneni K, Siddamreddy S, Avula A, et al: Spectrum of neuropsychiatric manifestations in COVID-19. Brain Behav Immun 88: 71-74, 2020.

3. Mao L, Jin H, Wang M, Hu Y, Chen S, He Q, Chang J, Hong C, Zhou Y, Wang D, et al: Neurologic manifestations of hospitalized patients with coronavirus disease 2019 in Wuhan, China. JAMA Neurol 77: 683-690, 2020.

4. Han H, Yang L, Liu R, Liu F, Wu KL, Li J, Liu XH and Zhu CL: Prominent changes in blood coagulation of patients with SARS-CoV-2 infection. Clin Chem Lab Med 58: 1116-1120, 2020.

5. Tang N, Li D, Wang X and Sun Z: Abnormal coagulation parameters are associated with poor prognosis in patients with novel coronavirus pneumonia. J Thromb Haemost 18: 844-847, 2020.
6. Yin S, Huang M, Li D and Tang N: Difference of coagulation features between severe pneumonia induced by SARS-CoV2 and non-SARS-CoV2. J Thromb Thrombolysis: 1-4, 2020.

7. Helms J, Tacquard C, Severac F, Leonard-Lorant I, Ohana M, Delabranche X, Merdji H, Clere-Jehl R, Schenck M, Fagot Gandet F, et al: High risk of thrombosis in patients with severe SARS-CoV-2 infection: A multicenter prospective cohort study. Intensive Care Med 46: 1089-1098, 2020.

8. Whyte CS, Morrow GB, Mitchell JL, Chowdary P and Mutch NJ: Fibrinolytic abnormalities in acute respiratory distress syndrome (ARDS) and versatility of thrombolytic drugs to treat COVID-19. J Thromb Haemost 18: 1548-1555, 2020.

9. Wichmann D, Sperhake JP, Lütgehetmann M, Steurer S, Edler C, Heinemann A, Heinrich F, Mushumba H, Kniep I, Schröder AS, et al: Autopsy findings and venous thromboembolism in patients With COVID-19: A prospective cohort study. Ann Intern Med 173: 268-277, 2020.

10. Xiong M, Liang X and Wei YD: Changes in blood coagulation in patients with severe coronavirus disease 2019 (COVID-19): A meta-analysis. Br J Haematol 189: 1050-1052, 2020.

11. Lodigiani C, Iapichino G, Carenzo L, Cecconi M, Ferrazzi P, Sebastian T, Kucher N, Studt JD, Sacco C, Bertuzzi A, et al: Venous and arterial thromboembolic complications in COVID-19 patients admitted to an academic hospital in Milan, Italy. Thromb Res 191: 9-14, 2020.

12. Avula A, Nalleballe K, Narula N, Sapozhnikov S, Dandu V, Toom S, Glaser A and Elsayegh D: COVID-19 presenting as stroke. Brain Behav Immun 87: 115-119, 2020.

13. Fara MG, Stein LK, Skliut M, Morgello S, Fifi JT and DhamoonrMS: Macrothrombosis and stroke in patients with mild Covid-19 infection. J Thromb Haemost 18: 2031-2033, 2020.

14. Beyrouti R, Adams ME, Benjamin L, Cohen H, Farmer SF, Goh YY, Humphries F, Jäger HR, Losseff NA, Perry RJ, et al: Characteristics of ischaemic stroke associated with COVID-19. J Neurol Neurosurg Psychiatry 91: 889-891, 2020.

15. Li YC, Bai WZ and Hashikawa T: The neuroinvasive potential of SARS-CoV2 may play a role in the respiratory failure of COVID-19 patients. J Med Virol 92: 552-555, 2020.

16. Yaghi S, Ishida K, Torres J, Mac Grory B, Raz E, Humbert K, Henninger N, Trivedi T, Lillemoe K, Alam S, et al: SARS-CoV-2 and stroke in a New York healthcare system. Stroke 51: 2002-2011, 2020

17. Oxley TJ, Mocco J, Majidi S, Kellner CP, Shoirah H, Singh IP, De Leacy RA, Shigematsu T, Ladner TR, Yaeger KA, et al: Large-vessel stroke as a presenting feature of Covid-19 in the young. N Engl J Med 382: e60, 2020.

18. Pacha O, Sallman MA and Evans SE: COVID-19: A case for inhibiting IL-17? Nat Rev Immunol 20: 345-346, 2020.

19. Mehta P, McAuley DF, Brown M, Sanchez E, Tattersall RS and Manson JJ; HLH Across Speciality Collaboration, UK: COVID-19: Consider cytokine storm syndromes and immunosuppression. Lancet 395: 1033-1034, 2020.

20. Sawdey MS and Loskutoff DJ: Regulation of murine type 1 plasminogen activator inhibitor gene expression in vivo. Tissue specificity and induction by lipopolysaccharide, tumor necrosis factor-alpha, and transforming growth factor-beta. J Clin Invest 88: 1346-1353, 1991.

21. Fourrier F, Chopin C, Goudemand J, Hendrycx S, Caron C, Rime A, Marey A and Lestavel P: Septic shock, multiple organ failure, and disseminated intravascular coagulation. Compared patterns of antithrombin III, protein $\mathrm{C}$, and protein $\mathrm{S}$ deficiencies. Chest 101: 816-823, 1992.

22. Jose RJ and Manuel A: COVID-19 cytokine storm: The interplay between inflammation and coagulation. Lancet Respir Med 8: e46-e47, 2020.

23. Hudock KM, Collins MS, Imbrogno M, Snowball J, Kramer EL, Brewington JJ, Gollomp K, McCarthy C, Ostmann AJ, Kopras EJ, et al: Neutrophil extracellular traps activate IL-8 and IL-1 expression in human bronchial epithelia. Am J Physiol Lung Cell Mol Physiol 319: L137-L147, 2020.

24. Pliyev BK and Menshikov M: Differential effects of the autophagy inhibitors 3-methyladenine and chloroquine on spontaneous and TNF- $\alpha$-induced neutrophil apoptosis. Apoptosis 17: 1050-1065, 2012.

25. Varga Z, Flammer AJ, Steiger P, Haberecker M, Andermatt R, Zinkernagel AS, Mehra MR, Schuepbach RA, Ruschitzka F and Moch H: Endothelial cell infection and endotheliitis in COVID-19. Lancet 395: 1417-1418, 2020. 
26. Leisman DE, Deutschman CS and Legrand M: Facing COVID-19 in the ICU: Vascular dysfunction, thrombosis, and dysregulated inflammation. Intensive Care Med 46: 1105-1108, 2020.

27. Li T, Wang C, Liu Y, Li B, Zhang W, Wang L, Yu M, Zhao X, Du J, Zhang J, et al: Neutrophil extracellular traps induce intestinal damage and thrombotic tendency in inflammatory bowel disease. J Crohns Colitis 14: 240-253, 2020.

28. Zubair AS, McAlpine LS, Gardin T, Farhadian S, Kuruvilla DE and Spudich S: Neuropathogenesis and neurologic manifestations of the coronaviruses in the age of coronavirus disease 2019 : A review. JAMA Neurol 77: 1018-1027, 2020.

29. Al Saiegh F, Ghosh R, Leibold A, Avery MB, Schmidt RF, Theofanis T, Mouchtouris N, Philipp L, Peiper SC, Wang ZX, et al: Status of SARS-CoV-2 in cerebrospinal fluid of patients with COVID-19 and stroke. J Neurol Neurosurg Psychiatry 91: 846-848, 2020

30. Chen N, Zhou M, Dong X, Qu J, Gong F, Han Y, Qiu Y, Wang J, Liu Y, Wei Y, et al: Epidemiological and clinical characteristics of 99 cases of 2019 novel coronavirus pneumonia in Wuhan, China: A descriptive study. Lancet 395: 507-513, 2020.

31. Xu P, Zhou Q and Xu J: Mechanism of thrombocytopenia in COVID-19 patients. Ann Hematol 99: 1205-1208, 2020.

32. Hottz ED, Bozza FA and Bozza PT: Platelets in immune response to virus and immunopathology of viral infections. Front Med (Lausanne) 5: 121, 2018.

33. Zhou P, Li T, Jin J, Liu Y, Li B, Sun Q, Tian J, Zhao H, Liu Z, $\mathrm{Ma} S$, et al: Interactions between neutrophil extracellular traps and activated platelets enhance procoagulant activity in acute stroke patients with ICA occlusion. EBioMedicine 53: 102671 , 2020.

34. Brinkmann V, Reichard U, Goosmann C, Fauler B, Uhlemann Y, Weiss DS, Weinrauch Y and Zychlinsky A: Neutrophil extracellular traps kill bacteria. Science 303: 1532-1535, 2004.

35. Martinod K and Wagner DD: Thrombosis: Tangled up in NETs. Blood 123: 2768-2776, 2014

36. Barnes BJ, Adrover JM, Baxter-Stoltzfus A, Borczuk A, Cools-Lartigue J, Crawford JM, Dassler-Plenker J, Guerci P, Huynh C, Knight JS, et al: Targeting potential drivers of COVID-19: Neutrophil extracellular traps. J Exp Med 217: e20200652, 2020

37. Zuo Y, Yalavarthi S, Shi H, Gockman K, Zuo M, Madison JA Blair C, Weber A, Barnes BJ, Egeblad M, et al: Neutrophil extracellular traps in COVID-19. JCI Insight 5: e138999, 2020.

38. Hargett LA and Bauer NN: On the origin of microparticles: From 'platelet dust' to mediators of intercellular communication. Pulm Circu 3: 329-340, 2013.

39. Yao Z, Wang L, Wu X, Zhao L, Chi C, Guo L, Tong D, Yang X, Dong Z, Deng R, et al: Enhanced procoagulant activity on blood cells after acute ischemic stroke. Transl Stroke Res 8: 83-91, 2017.

40. Yu M, Xie R, Zhang Y, Liang H, Hou L, Yu C, Zhang J, Dong Z, Tian Y, Bi Y, et al: Phosphatidylserine on microparticles and associated cells contributes to the hypercoagulable state in diabetic kidney disease. Nephrol Dial Transplant 33: 2115-2127, 2018.

41. Vance JE and Steenbergen R: Metabolism and functions of phosphatidylserine. Prog Lipid Res 44: 207-234, 2005.

42. Wang Y, Du F, Hawez A, Mörgelin M and Thorlacius H: Neutrophil extracellular trap-microparticle complexes trigger neutrophil recruitment via high-mobility group protein 1 (HMGB1)-toll-like receptors(TLR2)/TLR4 signalling. Br J Pharmacol 176: 3350-3363, 2019.

43. Wang Y, Luo L, Braun OÖ, Westman J, Madhi R, Herwald H, Mörgelin $M$ and Thorlacius H: Neutrophil extracellular trap-microparticle complexes enhance thrombin generation via the intrinsic pathway of coagulation in mice. Sci Rep 8: 4020, 2018.

44. Nieri D, Neri T, Petrini S, Vagaggini B, Paggiaro P and Celi A: Cell-derived microparticles and the lung. Eur Respir Rev 25: 266-277, 2016

45. Balvers K, Curry N, Kleinveld DJ, Böing AN, Nieuwland R, Goslings JC and Juffermans NP: Endogenous microparticles drive the proinflammatory host immune response in severely injured trauma patients. Shock 43: 317-321, 2015.

46. Riedl M,Fakhouri F, Le Quintrec M, Noone DG, Jungraithmayr TC, Fremeaux-Bacchi V and Licht C: Spectrum of complement-mediated thrombotic microangiopathies: Pathogenetic insights identifying novel treatment approaches. Semin Thromb Hemost 40: 444-464, 2014.

47. Cugno M, Meroni PL, Gualtierotti R, Griffini S, Grovetti E, Torri A, Panigada M, Aliberti S, Blasi F, Tedesco F and Peyvandi F: Complement activation in patients with COVID-19: A novel therapeutic target. J Allergy Clin Immunol 146: 215-217, 2020.
48. Magro C, Mulvey JJ, Berlin D, Nuovo G, Salvatore S, Harp J, Baxter-Stoltzfus A and Laurence J: Complement associated microvascular injury and thrombosis in the pathogenesis of severe COVID-19 infection: A report of five cases. Transl Res 220: 1-13, 2020.

49. Stites E, Renner B, Laskowski J, Le Quintrec M, You Z, Freed B, Cooper J, Jalal D and Thurman JM: Complement fragments are biomarkers of antibody-mediated endothelial injury. Mol Immunol 118: 142-152, 2020.

50. Heydenreich N, Nolte MW, Göb E, Langhauser F, Hofmeister M, Kraft P, Albert-Weissenberger C, Brede M, Varallyay C, Göbel K, et al: C1-inhibitor protects from brain ischemia-reperfusion injury by combined antiinflammatory and antithrombotic mechanisms. Stroke 43: 2457-2467, 2012.

51. Pugh CW and Ratcliffe PJ: New horizons in hypoxia signaling pathways. Exp Cell Res 356: 116-121, 2017.

52. Cameron SJ, Mix DS, Ture SK, Schmidt RA, Mohan A, Pariser D, Stoner MC, Shah P, Chen L, Zhang H, et al: Hypoxia and ischemia promote a maladaptive platelet phenotype. Arterioscler Thromb Vasc Biol 38: 1594-1606, 2018.

53. Gupta N, Zhao YY and Evans CE: The stimulation of thrombosis by hypoxia. Thromb Res 181: 77-83, 2019.

54. Frangou E, Chrysanthopoulou A, Mitsios A, Kambas K, Arelaki S, Angelidou I, Arampatzioglou A, Gakiopoulou H, Bertsias GK, Verginis $\mathrm{P}$, et al: REDD1/autophagy pathway promotes thromboinflammation and fibrosis in human systemic lupus erythematosus (SLE) through NETs decorated with tissue factor (TF) and interleukin-17A (IL-17A). Ann Rheum Dis 78: 238-248, 2019.

55. Zhang Y, Xiao M, Zhang S, Xia P, Cao W, Jiang W, Chen H, Ding X, Zhao H, Zhang H, et al: Coagulopathy and antiphospholipid antibodies in patients with Covid-19. N Engl J Med 382: e38, 2020

56. Müller-Calleja N, Hollerbach A, Ritter S, Pedrosa DG, Strand D, Graf C, Reinhardt C, Strand S, Poncelet P, Griffin JH, et al: Tissue factor pathway inhibitor primes monocytes for antiphospholipid antibody-induced thrombosis. Blood 134: 1119-1131, 2019.

57. Gašperšič N, Zaletel M, Kobal J, Žigon P, Čučnik S, Šemrl SS, Tomšič $M$ and Ambrožič A: Stroke and antiphospholipid syndrome-antiphospholipid antibodies are a risk factor for an ischemic cerebrovascular event. Clin Rheumatol 38: 379-384, 2019

58. Tang N, Bai H, Chen X, Gong J, Li D and Sun Z: Anticoagulant treatment is associated with decreased mortality in severe coronavirus disease 2019 patients with coagulopathy. J Thromb Haemost 18: 1094-1099, 2020.

59. Oudkerk M, Buller HR and Kuijpers D: Diagnosis, prevention, and treatment of thromboembolic complications in COVID-19: Report of the National Institute for Public Health of the Netherlands. Radiology 297: E216-E222, 2020.

60. Klok FA, Kruip MJHA, van der Meer NJM, Arbous MS, Gommers DAMPJ, Kant KM, Kaptein FHJ, van Paassen J, Stals MAM, Huisman MV and Endeman H: Incidence of thrombotic complications in critically ill ICU patients with COVID-19. Thromb Res 191: 145-147, 2020.

61. Bikdeli B, Madhavan MV, Jimenez D, Chuich T, Dreyfus I, Driggin E, Nigoghossian C, Ageno W, Madjid M, Guo Y, et al: COVID-19 and thrombotic or thromboembolic disease: Implications for prevention, antithrombotic therapy, and follow-up. J Am Coll Cardiol 75: 2950-2973, 2020.

62. Hermans $C$ and Lambert C: Impact of the COVID-19 pandemic on therapeutic choices in thrombosis-hemostasis. J Thromb Haemost 18: 1794-1795, 2020.

63. Wang J, Hajizadeh N, Moore EE, McIntyre RC, Moore PK, Veress LA, Yaffe MB, Moore HB and Barrett CD: Tissue plasminogen activator (tPA) treatment for COVID-19 associated acute respiratory distress syndrome (ARDS): A case series. J Thromb Haemost 18: 1752-1755, 2020.

64. Quiros Roldan E, Biasiotto G, Magro P and Zanella I: The possible mechanisms of action of 4-aminoquinolines (chloroquine/hydroxychloroquine) against Sars-Cov-2 infection (COVID-19): A role for iron homeostasis? Pharmacol Res 158: 104904, 2020.

65. Rodrigues-Diez RR, Tejera-Muñoz A, Marquez-Exposito L, Rayego-Mateos S, Sanchez LS, Marchant V, Santamaria LT, Ramos AM,Ortiz A, Egido J and Ruiz-Ortega M: Statins: Could an old friend help the fight against COVID-19? Br J Pharmacol 177: 4873-4886, 2020

66. Ascierto PA, Fox BA, Urba WJ, Anderson AC, Atkins MB, Borden EC, Brahmer JR, Butterfield LH, Cesano A, Chen DC, et al: Insights from immuno-oncology: The Society for Immunotherapy of Cancer Statement on access to IL-6-targeting therapies for COVID-19. J Immunother Cancer 8: e000878, 2020. 
67. Paniri A and Akhavan-Niaki H: Emerging role of IL-6 and NLRP3 inflammasome as potential therapeutic targets to combat COVID-19: Role of lncRNAs in cytokine storm modulation. Life Sci: 118114, 2020.

68. Alhenc-Gelas F and Drueke TB: Blockade of SARS-CoV-2 infection by recombinant soluble ACE2. Kidney Int 97: 1091-1093, 2020.

69. Haschke M, Schuster M, Poglitsch M, Loibner H, Salzberg M, Bruggisser M, Penninger J and Krähenbühl S: Pharmacokinetics and pharmacodynamics of recombinant human angiotensin-converting enzyme 2 in healthy human subjects. Clin Pharmacokinet 52: 783-792, 2013.

70. Khan A, Benthin C, Zeno B, Albertson TE, Boyd J, Christie JD, Hall R, Poirier G, Ronco JJ, Tidswell M, et al: A pilot clinical trial of recombinant human angiotensin-converting enzyme 2 in acute respiratory distress syndrome. Crit Care 21: 234, 2017.

71. Sardu C, Gambardella J, Morelli MB, Wang X, Marfella R and Santulli G: Hypertension, thrombosis, kidney failure, and diabetes: Is COVID-19 an endothelial disease? A comprehensive evaluation of clinical and basic evidence. J Clin Med 9: 1417, 2020.

72. Fan E, Brodie D and Slutsky AS: Acute respiratory distress syndrome: Advances in diagnosis and treatment. JAMA 319 698-710, 2018

73. Pulavendran S, Rudd JM, Maram P, Thomas PG, Akhilesh R, Malayer JR, Chow VTK and Teluguakula N: Combination therapy targeting platelet activation and virus replication Protects mice against lethal influenza pneumonia. Am J Respir Cell Mol Biol 61: 689-701, 2019

74. De Meyer SF, Suidan GL, Fuchs TA, Monestier M and Wagner DD: Extracellular chromatin is an important mediator of ischemic stroke in mice. Arterioscler Thromb Vasc Biol 32: 1884-1891, 2012.

75. Papayannopoulos V, Staab D and Zychlinsky A: Neutrophil elastase enhances sputum solubilization in cystic fibrosis patients receiving DNase therapy. PLoS One 6: e28526, 2011.

76. Laridan E, Denorme F, Desender L, François O, Andersson T Deckmyn H, Vanhoorelbeke K and De Meyer SF: Neutrophil extracellular traps in ischemic stroke thrombi. Ann Neurol 82: 223-232, 2017.

77. Mistry P, Carmona-Rivera C, Ombrello AK, Hoffmann P, Seto NL, Jones A, Stone DL, Naz F, Carlucci P, Dell'Orso S, et al Dysregulated neutrophil responses and neutrophil extracellular trap formation and degradation in PAPA syndrome. Ann Rheum Dis 77: 1825-1833, 2018

78. Kim SW, Lee H, Lee HK, Kim ID and Lee JK: Neutrophil extracellular trap induced by HMGB1 exacerbates damages in the ischemic brain. Acta Neuropathol Commun 7: 94, 2019.

79. Neri T, Scalise V, Passalacqua I, Sanguinetti C, Lombardi S, Pergoli L, Bollati V, Pedrinelli R, Paggiaro P and Celi A: Tiotropium inhibits proinflammatory microparticle generation by human bronchial and endothelial cells. Sci Rep 9: 11631, 2019.

80. Neri T, Lombardi S, Faìta F, Petrini S, Balìa C, Scalise V, Pedrinelli R, Paggiaro P and Celi A: Pirfenidone inhibits p38-mediated generation of procoagulant microparticles by human alveolar epithelial cells. Pulm Pharmacol Ther 39: 1-6, 2016.

81. Gralinski LE, Sheahan TP, Morrison TE, Menachery VD, Jensen K, Leist SR, Whitmore A, Heise MT and Baric RS: Complement activation contributes to severe acute respiratory syndrome coronavirus pathogenesis. mBio 9: e01753-18, 2018.

82. Mastellos DC, Ricklin D and Lambris JD: Clinical promise of next-generation complement therapeutics. Nat Rev Drug Discov 18: 707-729, 2019.

83. Hadanny A, Rittblat M, Bitterman M, May-Raz I, Suzin G, Boussi-Gross R, Zemel Y, Bechor Y, Catalogna M and Efrati S Hyperbaric oxygen therapy improves neurocognitive functions of post-stroke patients-a retrospective analysis. Restor Neurol Neurosci 38: 93-107, 2020

84. Beyls C, Huette P, Abou-Arab O, Berna P and Mahjoub Y: Extracorporealmembrane oxygenation forCOVID-19-associated severe acute respiratory distress syndrome and risk of thrombosis. Br J Anaesth 125: e260-e262, 2020.
85. Fan H, Zhang L, Huang B, Zhu M, Zhou Y, Zhang H, Tao X, Cheng S, Yu W, Zhu L and Chen J: Cardiac injuries in patients with coronavirus disease 2019: Not to be ignored. Inter J Infect Dis 96: 294-297, 2020.

86. Zou Y, Guo H, Zhang Y, Zhang Z, Liu Y, Wang J, Lu H and Qian Z: Analysis of coagulation parameters in patients with COVID-19 in Shanghai, China. Biosci Trends 14: 285-289, 2020.

87. Fogarty H, Townsend L, Ni Cheallaigh C, Bergin C, Martin-Loeches I, Browne P, Bacon CL, Gaule R, Gillett A, Byrne M, et al: COVID19 coagulopathy in Caucasian patients. Br J Haematol 189: 1044-1049, 2020.

88. Huang C, Wang Y, Li X, Ren L, Zhao J, Hu Y, Zhang L, Fan G, Xu J, Gu X, et al: Clinical features of patients infected with 2019 novel coronavirus in Wuhan, China. Lancet 395: 497-506, 2020.

89. Wu C, Chen X, Cai Y, Xia J, Zhou X, Xu S, Huang H, Zhang L, Zhou X, Du C, et al: Risk factors associated with acute respiratory distress syndrome and death in patients with coronavirus disease 2019 pneumonia in Wuhan, China. JAMA Intern Med 180: 934-943, 2020

90. Cui S, Chen S, Li X, Liu S and Wang F: Prevalence of venous thromboembolism in patients with severe novel coronavirus pneumonia. J Thromb Haemost 18: 1421-1424, 2020.

91. Stoneham SM, Milne KM, Nuttall E, Frew GH, Sturrock BR, Sivaloganathan H, Ladikou EE, Drage S, Phillips B, Chevassut TJ and Eziefula AC: Thrombotic risk in COVID-19: A case series and case-control study. Clin Med (Lond) 20: e76-e81, 2020.

92. Léonard-Lorant I, Delabranche X, Séverac F, Helms J, Pauzet C, Collange $\mathrm{O}$, Schneider $\mathrm{F}$, Labani $\mathrm{A}$, Bilbault $\mathrm{P}$, Molière $\mathrm{S}$, et al: Acute pulmonary embolism in COVID-19 patients on CT angiography and relationship to D-Dimer levels. Radiology 296: E189-E191, 2020

93. Llitjos JF, Leclerc M, Chochois C, Monsallier JM, Ramakers M, Auvray M and Merouani K: High incidence of venous thromboembolic events in anticoagulated severe COVID-19 patients. J Thromb Haemost 18: 1743-1746, 2020.

94. Poillon G, Obadia M, Perrin M, Savatovsky J and Lecler A Cerebral venous thrombosis associated with COVID-19 infection: Causality or coincidence? J Neuroradiol: S0150-986: 30167-X, 2020.

95. Paranjpe I, Fuster V, Lala A, Russak AJ, Glicksberg BS Levin MA, Charney AW, Narula J, Fayad ZA, Bagiella E, et al: Association of treatment dose anticoagulation with in-hospital survival among hospitalized patients with COVID-19. J Am Coll Cardiol 76: 122-124, 2020.

96. WhiteD,MacDonaldS,BullT,Hayman M,de Monteverde-RobbR, Sapsford D, Lavinio A, Varley J, Johnston A, Besser M and Thomas W: Heparin resistance in COVID-19 patients in the intensive care unit. J Thromb Thrombolysis 50: 287-291, 2020.

97. Arachchillage DJ, Remmington C, Rosenberg A, Xu T, Passariello M, Hall D, Laffan M and Patel BV: Anticoagulation with argatroban in patients with acute antithrombin deficiency in severe COVID-19. Br J Haematol 190: e286-e288, 2020.

98. Ranucci M, Ballotta A, Di Dedda U, Bayshnikova E, Dei Poli M, Resta M, Falco M, Albano G and Menicanti L: The procoagulant pattern of patients with COVID-19 acute respiratory distress syndrome. J Thromb Haemost 18: 1747-1751, 2020.

99. Thachil J, Tang N, Gando S, Falanga A, Cattaneo M, Levi M, Clark $\mathrm{C}$ and Iba T: ISTH interim guidance on recognition and management of coagulopathy in COVID-19. J Thromb Haemost 18: 1023-1026, 2020

100. Connors JM and Levy JH: COVID-19 and its implications for thrombosis and anticoagulation. Blood 135: 2033-2040, 2020.

101. Thachil J, Tang N, Gando S, Falanga A, Cattaneo M, Levi M, Clark C and Iba T: DOACs and 'newer' haemophilia therapies in COVID-19. J Thromb Haemost 18: 1795-1796, 2020.

102. Bikdeli B, Madhavan MV, Gupta A, Jimenez D, Burton JR, Der Nigoghossian C, Chuich T, Nouri SN, Dreyfus I, Driggin E, et al: Pharmacological agents targeting thromboinflammation in COVID-19: Review and implications for future research. Thromb Haemost 120: 1004-1023, 2020

This work is licensed under a Creative Commons Attribution-NonCommercial-NoDerivatives 4.0 International (CC BY-NC-ND 4.0) License. 